\title{
DERROTANDO NORMAS EM USO: O PENSAMENTO FALIBILISTA APLICADO À LÓGICA DA ARGUMENTAÇÃO
}

\author{
DEFEASIBILITY AND LEGAL RULES: THE FALLIBILISTIC APPROACH \\ APPLIED TO THE LOGIC OF LEGAL ARGUMENTATION
}

Adriana Reis de Albuquerque ${ }^{1}$

\begin{abstract}
RESUMO
O presente artigo tem por objetivo discutir a noção de derrotabilidade das normas jurídicas, em sua correlação com a epistemologia falibilista. $\mathrm{O}$ texto evidencia que o pensamento falibilista, para além de ser aplicado ao âmbito da teorização acerca do caráter científico do Direito, também pode se voltar ao próprio Direito enquanto objeto, tanto para fins de atribuição de sentido aos termos normativos, quanto para fins de aplicação na esfera probatória, cenário no qual se constrói o conceito de derrotabilidade. A partir de textos de Henry Prakken, Giovanni Sartor e Frederick Schauer, o artigo evidencia as raízes epistemológicas e lógicas do conceito de derrotabilidade, analisando-o em suas perspectivas estática e dinâmica, nas vertentes da derrotabilidade inferencial, baseada no processo e baseada na teoria. Demonstra sua aptidão para minimizar o decisionismo e o psicologismo da decisão judicial, para modular o mecanismo de atribuição do ônus da prova e de sua apreciação no bojo do processo e para impor ao juiz o dever de justificação completa e coerente acerca dos fatos. Defende que o seu uso possibilita o desenvolvimento de uma prática argumentativa que admite a complexidade discursiva do Direito em todas as suas vertentes e interações sem precisar abrir mão da racionalidade e da lógica.
\end{abstract}

Palavras-chave: Epistemologia falibilista; derrotabilidade; lógica não monotônica; argumentação jurídica; racionalidade.

\begin{abstract}
The present study has the objective of discussing the notion of defeasibility of legal norms in their correlation with fallibilist epistemology. This essay demonstrates that fallibilist thought, besides being applied to the scope of theorization regarding the scientific character of law, can also turn to law itself as an object, in order to attribute meaning to normative terms, as well as to be applied in the probative sphere, the scenario in which the concept of defeasibility is built. Considering the texts of Henry Prakken, Giovanni Sartor and Frederick Schauer, this article demonstrates the epistemological and logical roots of the concept of defeasibility, analyzing it in both its static and dynamic perspectives, in the aspects of inferential defeasibility, based on the process and based on the theory. This study demonstrates its aptitude to minimize the

\footnotetext{
${ }^{1}$ Doutoranda em Direito na Universidade Federal do Ceará. Mestre em Direito pela UFPE. Especialista em Direito Tributário pelo IBET. Especialista em Integração Econômica e Direito Internacional Fiscal pela FGV/ESAF. Especialista em Administração Pública pela FGV. Procuradora da Fazenda Nacional. Universidade Federal do Ceará - UFC, Ceará - Brasil. ORCID: https://orcid.org/0000-0003-3856-2810 Lattes: http://lattes.cnpq.br/3665089817327335 E-mail: adri_london@hotmail.com
} 
decisionism and the psychologism of the judicial decision, to modulate the mechanism of attribution of the burden of proof and its assessment in the context of the process as well as to impose on the judge the duty to provide complete coherent justification regarding the facts. This article defends that its use makes it possible to develop an argumentative practice that admits discursive complexity of law in all its aspects and interactions without having to let go of rationality and logic.

Keywords: Epistemic Fallibilism; defeasibility; non-monotonic logic; legal argumentation; rationality.

\section{INTRODUÇÃO}

Dentro da teoria da ciência, a epistemologia dirige-se ao estudo dos aspectos materiais do conhecimento humano, tendo por foco a análise do fenômeno do conhecimento enquanto relação "sujeito - imagem (pensamento) - objeto" e dos problemas nele contidos. A teoria do conhecimento não se preocupa com a correção do pensamento, que é o foco da lógica, mas sim com o problema da correspondência entre pensamento e objeto, com o problema da verdade. A lógica, por sua vez, se volta ao estudo da correção formal do pensamento, buscando analisar as suas formas e leis gerais e corrigir eventuais incoerências no procedimento de sua construção (HESSE, 2003). Epistemologia e lógica, no entanto, embora distintas, apresentam evidente relação.

No âmbito da epistemologia, adquire relevância para o estudo do Direito a epistemologia falibilista, tal como desenvolvida por Popper. O pensamento falibilista tanto pode ser aplicado ao âmbito da teorização do Direito, para fins de determinação de sua natureza, do que faz dele ciência ou de qual sua função, quanto ao próprio Direito enquanto objeto, a partir da análise da ideia de derrotabilidade.

Por uma questão de coerência, e partindo-se da premissa de que a teorização do Direito tem evidente relação com a sua prática e é por ela retroalimentada, a adoção do pensamento falibilista em sede de teorização do Direito produz um ambiente de aceitação de uma perspectiva derrobatibilista também em sua aplicação concreta.

No entanto, o conceito de derrotalidade, que encontra raízes tanto na epistemologia quanto na lógica, embora absolutamente relevante à compreensão da estrutura argumentativa do Direito, nele ainda é pouco estudado ${ }^{2}$, embora já tenha recebido considerável análise no âmbito da filosofia.

\footnotetext{
${ }^{2}$ O termo foi utilizado pela primeira vez por Hart, em 1949, no texto "Ascription of Responsability and Rights".
} 
A partir especialmente de textos de Henry Prakken, Giovanni Sartor e Frederick Schauer, o presente texto evidencia as raízes epistemológicas e lógicas da ideia derrotabilidade, para sustentar a adequação de sua utilização no fenômeno argumentativo do Direito.

Discorre-se brevemente acerca da epistemologia falibilista, mas ela não é o foco prioritário da análise.

A compreensão do falibilismo é relevante porque, uma vez adotado, ele estabelece um macro cenário no qual o Direito não pode mais ser construído, explicado nem aplicado a partir da utilização isolada da lógica formal clássica e da consequente construção das normas jurídicas enquanto silogismos dedutivos, esquemas argumentativos monotônicos e conclusivos (SARTOR, 2012). Assim, embora o texto tenha por propósito tratar de derrotabilidade, do afastamento da norma jurídica em uso, aspectos de teoria do Direito e sua prática serão constantemente correlacionados.

Em uma perspectiva falibilista, o direito passa a ser compreendido como um sistema complexo $^{3}$, a demandar, especialmente no âmbito da sua aplicação, a utilização de uma lógica de natureza distinta, capaz de se adequar às estruturas do conhecimento jurídico, do seu padrão de argumentação e da dialética de sua interação.

Quando inicialmente aplicada ao Direito, a lógica tradicional, assentada na preservação da verdade, terminou por dar origem a um "dedutivismo ingênuo" (PRAKKEN, 1997), que conduziu ao formalismo, ao legalismo extremo, ao raciocínio baseado em regras. A utilização da derrotabilidade no âmbito da argumentação jurídica, assentada na concepção epistemológica falibilista, pressupõe a superação desta visão e a consequente percepção, a partir do estudo de lógicas como a não monotônica, de que é possível obter lógica e racionalidade mesmo em contextos de ausência de informação, de incerteza, de conflito, no bojo de uma compreensão não reducionista do Direito.

Por fim, o texto trabalha a derrotabilidade aplicada ao Direito, pontuando sua importância no âmbito da argumentação, tanto para fins de atribuição de sentido aos termos normativos, quanto no âmbito probatório.

\footnotetext{
${ }^{3}$ O termo complexo é aqui utilizado não no sentido de "difícil", mas de sistema complexo, tal como entendido pela Teoria da Complexidade. Veja-se: MITCHELL, Melanie. Complexity, a guided tour. Oxford Oxford University Press, 2009. MORIN, Edgar. Introducción al pensamiento complejo. Barcelona: Gedisa, 1998.
} 


\section{O DEDUTIVISMO INGÊNUO E SUA INFLUÊNCIA SOBRE A FORMULAÇÃO E A APLICAÇÃO DO DIREITO}

Na introdução do livro "O Erro de Descartes”, António Damásio (2018, p. 17) afirma que o escreveu com o intuito de propor "que a razão pode não ser tão pura quanto a maioria de nós pensa que é ou desejaria que fosse, e que as emoções e os sentimentos podem não ser de todo uns intrusos no bastião da razão".

Se atualmente, em tempos de falibilismo e ciências cognitivas, ainda há relevante resistência à adoção, no âmbito da ciência, de um conceito de razão que se afaste da pureza mencionada por Damásio, entre os séculos XVII e XIX esta vinculação entre ciência e objetividade atingiu seu extremo.

Na busca pela objetividade, a ciência adotou a lógica formal clássica como parâmetro de racionalidade e elegeu o método dedutivo, que lhe é típico, como o único aceitável. Fora de dedução, corria-se o risco da permeabilidade da subjetividade e da incerteza, vistos como incompatíveis com a método da ciência. A teoria, que ansiava pela universidade, foi considerada incompatível com métodos outros, tais como a indução, tida por inapta a ser considerada fonte do conhecimento, em virtude de sua incapacidade de gerar universalização rigorosa.

A transcendência da lei em relação à experiência fez com que se considerasse que a injunção não podia ser justificada em bases lógicas porque "é possível a conclusão de um argumento indutivo ser falsa embora as premissas sejam verdadeiras e, ainda assim, não haver contradição envolvida" (CHALMERS, 1993, p. 32). A ciência, àquele ponto, não estava disposta a lidar com o risco à segurança causado pela potencial superveniência de uma observação não abarcada pela universalização restrita do juízo indutivo.

Em Kant, a vinculação entre conhecimento científico e dedução foi estabelecida a partir da defesa de que a universalidade empírica é uma extensão arbitrária da validade, na qual se transfere para a totalidade dos casos a validade que é apenas da maioria.

Afastando a possibilidade de obtenção de universalidade rigorosa a partir da experiência, Kant a vincula à construção dos denominados juízos a priori, aqueles conhecimentos que se elevam acima do mundo sensível, em relação aos quais a experiência não pode dar fio condutor nem correção. Neste contexto, para Kant o grande desafio do conhecimento seria conseguir construir, aprioristicamente, com validade universal, afirmações que nos parecem demandar experiências anteriores (KANT, 2001). 
Inserido neste contexto, e pautado por pretensões de cientificidade, o Direito do século XIX adotou o método dedutivo e, em busca de segurança e previsibilidade, concebeu os sistemas jurídicos como sistemas axiomáticos, no âmbito dos quais os enunciados normativos operavam como dogmas, fazendo surgir o conceito de dogmática jurídica ${ }^{4}$.

$\mathrm{Na}$ medida em que estes enunciados impassíveis de questionamento também se encontravam inseridos em um ordenamento que era tido por completo e consistente, o processo de raciocínio jurídico se apresentava como em uma mera subsunção lógica que se limitava a escolher a lei aplicável e fazê-la incidir sobre as situações fáticas nela previstas. Porque esse dedutivismo parecia ingenuamente acreditar que seria capaz de solucionar todos os problemas do Direito, de eliminar o âmbito do desconhecido e de controlar o futuro, Henry Prakken (1997) o denomina de dedutivismo ingênuo.

Esta visão se exteriorizou inicialmente no dogmatismo legalista característico da Escola da Exegese, pautada no culto extremo ao texto da lei, a quem se atribuiu o monopólio da manifestação do Direito, na defesa de que as lacunas no Direito são meramente aparentes e na concepção de que o pensamento jurídico poderia ser resumido a um pensamento silogístico que tem na lei a sua premissa maior e nos fatos sua premissa menor.

Já no século XX, o dogmatismo se exteriorizou, agora já em uma perspectiva normativa, na Teoria pura do Direito de Kelsen que defendeu a necessidade de construção de uma ciência do Direito neutra, pautada em uma dupla purificação. No bojo da primeira purificação, deverse-ia afastar o "mundo do ser" e o mundo do "dever-ser", ante a concepção de que não caberia à ciência do Direito prescrever como o direito deveria ser, mas tão somente descrevê-lo como é. Todavia, sendo esta primeira purificação ainda insuficiente para afastar do Direito as influências por ventura recebidas de outros sistemas sociais, há, em Kelsen, a previsão de uma segunda purificação, que aparta o Direito da moral, tornando-o, supostamente, sob o ponto de vista descritivo, puro $^{5}$ (KELSEN, 2003).

A vinculação da ciência à utilização de um método dedutivo aplicado em perspectiva dogmática conferiu à racionalidade a função meramente instrumental de verificar o

\footnotetext{
${ }^{4} \mathrm{Na}$ sua utilização tradicional, o termo "dogmática jurídica" é empregado na acepção de um conhecimento não passível de "crítica", tido por acabado, que deve ser necessariamente reconhecimento como algo "dado" e intangível por qualquer refutação.

${ }^{5}$ A crítica à Kelsen decorre da concepção de que a descrição do que o Direito é, por parte do cientista, não tem como ser dissociada da ideia que o sujeito faz do que o Direito deve ser, na medida em que a concepção do intérprete acerca do que o Direito deve ser sempre interfere na forma como o Direito é por ele visto e descrito. É exatamente em função desta interferência que surgem diferenças interpretativas em relação a um mesmo texto e afirmações distintas em torno do Direito.
} 
cumprimento dos procedimentos lógicos-formais. Tendo por propósito assegurar a manutenção da moldura, a racionalidade se viu transformada em um "leito de Procusto"

Esta visão de índole estritamente dogmática, embora já há muito não corresponda exatamente à forma como o Direito é sistemicamente pensado, deixou marcas profundas em sua estrutura, e é a ela que se ainda está a criticar quando se questiona o inadequado caráter dogmático do Direito ${ }^{7}$.

Embora minimizado pela superveniência de flexibilizações posteriores, tais como o desenvolvimento da retórica e da hermenêutica jurídica em suas diversas vertentes, os resquícios deste dogmatismo ainda se evidenciam, de forma esparsa, tanto no âmbito da construção do ordenamento jurídico, quanto em sede de aplicação do Direito ${ }^{8}$.

\section{A INADEQUAÇÃo DA UTILIZAÇÃo (DOGMÁTICA) DA LÓGICA CLÁSSICA NO ÂMBITO DO RACIOCÍNIO JURÍDICO}

A lógica formal clássica, aplicada sob a forma do dedutivismo ingênuo, é claramente insuficiente para lidar com o fenômeno do Direito porque foi inicialmente desenvolvida para o âmbito da matemática, que é, por essência, um esquema monotônico de argumentação.

Sistemas monotônicos são sistemas de argumentação conclusivos no âmbito dos quais se opera uma transição cognitiva entre as pré-condições do esquema e as conclusões por ele validadas, razão pela qual a aceitação das pré-condições gera compulsoriamente a aceitação das conclusões que delas derivam (SARTOR, 2012) ${ }^{9}$.

\footnotetext{
${ }^{6}$ A história "o Leito de Procusto", da mitologia grega, relata que Procusto tinha uma cama de ferro do seu tamanho exato. Todos aqueles que eram acolhidos em sua casa, eram obrigados a deitar-se na sua cama. Se os viajantes não coubessem na cama, eram cortados ou esticados, consoante fossem altos ou baixos demais.

Nunca nenhum viajante se adaptava a cama, porque secretamente Procusto possuía duas camas de tamanho diferentes, escolhendo uma delas em função do viajante, que a ela precisava se adaptar.

${ }^{7}$ Exatamente porque o termo "dogmático" ainda é muito empregado na acepção de um conhecimento não passível de crítica, concepção na qual se torna incompatível com a Ciência, que é caracterizada pelo método científico, Hugo de Brito Machado Segundo propõe a não utilização da dicção "dogmática jurídica" para se fazer alusão à ciência do Direito. (MACHADO SEGUNDO, 2008).

${ }^{8} \mathrm{Na}$ ainda recente década de 60, o Direito Tributário, por exemplo, sofreu um "duplo corte constitutivo" que em muito lembra a "dupla purificação" kelseniana, nos termos do qual foi separado primeiro das Ciências das Finanças e depois do Direito Financeiro (NETO, 2016). Na busca por pureza metodológica, criou-se uma doutrina tributária que "concentrou-se em tentar realizar estudos descritivos do ordenamento jurídico tributário", a partir de uma "análise reducionista, voltada para o que já está feito (positivado), e fortemente preocupada com os aspectos semântico e sintático" (FOLLONI; SIMM, 2016, p. 52).

${ }^{9}$ Assentada na ideia da preservação da verdade, a dedução vincula a existência de verdade no antecedente do esquema à obtenção de verdade no seu consequente. É importante salientar que, sob o ponto de vista lógico, verdade é compreendida como correção formal do pensamento, não havendo qualquer espécie de conexão com o debate acerca de seu conceito epistemológico, seja o de verdade como correspondência para com o objeto, seja qualquer outro.
} 
Porque são esquemas regidos pelo critério de preservação da verdade, nos sistemas monotônicos a inclusão de novas informações apenas pode ter o condão de ampliar o volume do conhecimento disponível. Trata-se da noção matemática de conjuntos, a partir das noções de contém e está contido.

Assim, se A decorre, como conclusão, de um conjunto de informações $X$, a adição de novas premissas a $\mathrm{X}$, transformando-o em $\mathrm{X}+1$, nunca poderá conduzir ao resultado de "nãoA” (SARTOR, 2012). Nos esquemas conclusivos, porque as premissas são tidas por axiomas, a verdade silogística, compreendida como adequação, está sempre preservada.

Esta construção não é suficiente para a compreensão e para a aplicação do Direito exatamente porque, antes de qualquer coisa, o problema do Direito é propriamente o problema da justificação de suas premissas, da aceitabilidade das próprias pré-condições do esquema, quais sejam os enunciados normativos ${ }^{10}$.

Tal constatação não passou desapercebida por Chaim Perelman que criticando o silogismo dedutivo evidenciou, quando da construção do que denominou de "nova retórica", que enquanto a lógica formal está preocupada com a coerência entre as conclusões e as premissas, a argumentação jurídica opera no âmbito do conflito dialético, razão pela as suas conclusões não precisam ser deduzidas, mas justificadas (PERELMAN, 1979). O objeto da argumentação jurídica é o conflito, a comparação entre as evidências e os valores envolvidos na construção do raciocínio jurídico e isto não encontra espaço, segundo ele alega, na estrutura restrita da lógica.

A lógica clássica também se mostra ineficiente porque muitos dos enunciados normativos, insertos em ambiente de conflitos políticos, econômicos e sociais já na sua fase de elaboração, são dotados de elementos como a vagueza e a ambiguidade. Assim, a própria premissa da dedução - a interpretação do texto da lei - não pode ser estipulada a priori, mas tão somente no âmbito do contexto.

Enquanto na dedução silogística a premissa é necessariamente um "dado", um elemento estático carregado de certeza, no âmbito da argumentação jurídica ela já se evidencia, desde o início, como um "construído" de natureza mutável.

\footnotetext{
${ }^{10}$ É preciso conceber que há uma diferença entre adotar o texto legal como ponto de partida e adotá-lo como um ponto de partido contra o qual não se pode investir qualquer sorte de argumento. Ao se afirmar que a ciência do Direito não pode ser denominada de dogmática não se questiona a importância do enunciado e a necessidade de que a ele se recorra, mas se pontua que ele não pode ser considerado um dogma se o conceito do enunciado, por mais claro que ele seja, varia pelo menos em função do contexto.
} 
Embora o termo "vagueza" seja polissêmico, no âmbito da filosofia o seu tratamento perpassa pela compreensão do paradoxo ${ }^{11}$ Sorites, também denominado de "paradoxo do monte", no bojo do qual se procura determinar qual é o limite, estabelecer o exato momento ou a demarcação a partir da qual algo pode passar a ser considerado o que é.

O paradoxo do monte ${ }^{12}$ se propõe a debater qual é a quantidade certa para que passemos a considerar o acúmulo de um determinado objeto "um monte". Em que momento um monte de determinado objeto deixa de sê-lo quando vamos removendo unidades desse objeto? Quantos grãos de areia são necessários para que tenhamos um monte de areia?” (VAN DEEMTER, 2010)

Diante da vagueza, busca-se o estabelecimento de um marco preciso de divisão ${ }^{13}$ a partir do qual se possa, com exatidão, aplicar ou afastar o conceito, fenômeno a que se denomina de precificação. No entanto, esta constante tentativa de delimitação termina por assemelhar o conceito vago a um conceito preciso, retirando-lhe sua principal característica ontológica, que é a sua própria imprecisão.

A procura pela demarcação que separa as esferas de aplicabilidade e de não aplicabilidade do conceito vago decorre da adoção da questionável perspectiva de que todo conceito possui (ou deveria possuir) "uma fronteira exata, capaz de separar os objetos do mundo em duas classes: a dos objetos que caem sob o conceito e a dos que não caem" (GOULART, 2010, p. 207). Mas a tese de que conceitos vagos possuiriam deontologicamente limites bem definidos é contra intuitiva, porque desconsidera a influência exercida pelo contexto para fins de sua própria definição e aplicabilidade, de modo que "a fronteira precisa de um predicado ou

\footnotetext{
11 "A paradox is a situation in which a statement is proven, and so is the negation of that same statement. Something is made out to be true and false at the same time, in other words. It is in this most worrying kind of paradox that reasoning about vagueness entangles us" (VAN DEEMTER, 2010, p. 134)

$12 \mathrm{O}$ paradoxo Sorite pode ser formulado de diversas formas, em exteriorização matemática ou não. Sua ideia central pode ser assim exposta: "Suponha que Vitor tenha um monte de areia. Se retirarmos um grão de areia do monte, o que permanece continua sendo um monte. A retirada de somente um grão não faz com que o monte de Vitor se transforme em algo que não seja um monte. Se dois montes de areia se diferenciam por apenas um grão, tem-se ou dois montes ou nenhum. Assim, esse raciocínio nos conduz à paradoxal conclusão de que qualquer quantidade de grãos de areia é um monte, mesmo que seja apenas na quantidade de somente um grão." (GOULART, 2010, p. 204)

13 A denominada teoria epistêmica tenta solucionar o problema da vagueza e, portanto, o paradoxo Sorites, defendendo que toda vagueza é uma forma de ignorância. Assim, quando se pensa em quantos grãos de areia são capazes de formar um monte, deve-se admitir que há uma fronteira exata a partir da qual passa-se a ter um monte e não mais apenas grãos. O problema epistemológico da vagueza decorre, portanto, não da inexistência do limite, mas de não se saber onde ele exatamente reside para fins de aplicação do conceito. Mas se existe um limite preciso, mesmo que esse limite seja minimamente atravessado, essa pequena mudança fará diferença na aplicabilidade do conceito, de modo que se desconstrói a premissa do paradoxo Sorites, assentada na concepção de que pequenas variações, por serem imperceptíveis, quando comparadas com a eminentemente anterior, conduziriam sempre à mesma conclusão lógica (GOULART, 2010).
} 
conceito, se existir alguma, deve ser determinada inteiramente em virtude de como usamos esse predicado ou conceito" (GOULART, 2010, p. 214), não podendo ser estabelecida a priori.

Afinal, como estabelecer aprioristicamente o que significa "na medida do possível"? “Apropriado"? "Proporcional”? "Razoável”?

Ademais, mesmo os conceitos denominados de precisos, aqueles que não têm a vagueza e a ambiguidade como algo inato, podem ter o seu sentido alterado pelo contexto no qual estão inseridos, dando origem a normas jurídicas distintas, o que evidencia que o enunciado normativo não carrega em si mesmo qualquer significado que lhe seja próprio, independente da atividade interpretativa que o transforma em norma.

A utilização dogmática da lógica clássica conflita, ainda, com a constatação de que, ao contrário da matemática, típico esquema monotônico, o Direito se evidencia essencialmente como um sistema complexo, caracterizado pelo dinamismo e pela adaptabilidade.

Sistemas complexos são aqueles caracterizados pelo elemento da emergência, compreendida, para efeitos de Teoria da Complexidade, como o "surgimento de estruturas, padrões e propriedades novas e coesas durante o processo de auto-organização" do sistema (FOLLONI, 2017, p. 917).

O sistema, que se encontra em constante interação com o ambiente que o circunda, assimila e processa informação, bem como se adapta, na medida em que a entrada de novas informações em sua esfera pode - e não raras vezes provoca - mudanças substanciais em sua estrutura de comportamento, muitas vezes incapazes de serem previstas (MITCHELL, 2009). É como consequência do reconhecimento desta entropia antagônica, do reconhecimento da influência da desordem e do caos - e não de sua rejeição - e das interações que entre elas ocorrem que exsurgem novas e constantes organizações.

Ao longo do processo argumentativo que culmina nas decisões judiciais, diversos significados linguísticos possíveis entram em jogo e elementos não textuais são constantemente inseridos, a exemplo das pré-compreensões dos intérpretes, suas histórias de vida, teorias a que se vinculam, valores a partir dos quais foram formados (FOLLONI, 2017). Esses elementos pessoais, por sua vez, também têm algo de comunitário, "uma vez que a forma como cada sujeito compreende toda a sua circunstância depende de significados que são construídos no mundo" (FOLLONI, 2017, p. 928).

Há evidente influência recíproca, regida por ordem, mas também por desordem e contingência, entre cada componente do sistema jurídico e o todo do próprio sistema, bem como interpenetração com elementos extra sistêmicos. Vista desta forma, a norma jurídica que termina por ser aplicada ao caso concreto após a realização do processo interpretativo pode ser 
compreendida como uma "emergência" do dinâmico, não linear e complexo sistema de Direito (FOLLONI, 2017).

Por fim, há, na vida cognitiva, elementos que condicionam todo o procedimento de construção e/ou análise daquilo a que denominados de "conhecimento", esteja o termo sendo utilizado no sentido de senso comum ou de conhecimento científico (RESCHER, 2003) ${ }^{14}$. Os recursos cognitivos de que dispomos nunca nos permitem representar a realidade de forma completamente adequada em relação às condições presentes nos objetos com os quais nos relacionamos. A consciência da imperfeição da cognição humana e da incompletude e inconsistência do conhecimento por ela produzido não nos permite, no entanto, no tempo presente, identificar os déficits que o maculam, o que só pode ocorrer quando da superveniência de conhecimento futuro, gerando o paradoxo a que Rescher denomina de paradoxo do prefácio $^{15}$.

\section{LÓGICA NÃO MONOTÔNICA, ARGUMENTAÇÃO JURÍDICA E DERROTABILIDADE}

Mas Sartor (2006) alerta que a crítica à inaplicabilidade da lógica clássica dedutiva não significa que não exista nenhuma lógica, enquanto instrumento, passível de ser aplicada ao raciocínio argumentativo no Direito.

A postura do que Prakken antes denominou de dedutivismo ingênuo provocou ao Direito um imenso prejuízo porque vinculou, de forma inadequada, o uso da lógica na seara da argumentação à utilização isolada e/ou majoritária do método dedutivo, incapaz, por natureza, de instrumentar toda a sua complexidade, especialmente quando utilizado em perspectiva dogmática.

\footnotetext{
${ }^{14}$ Rescher identifica como condicionantes do processo de conhecimento as imperfeições cognitivas (cognitive imperfections), o abismo epistêmico (epistemic gap), as mudanças na compreensão em relação aos fatos existentes, ante a nossa natureza falível (cientific fallibilism), a consciência de que no âmbito do que denominados de "conhecimento", há fatos que desconhecemos (blind spots), a constatação de que nossas previsões mais acuradas também podem simplesmente falhar (predictive biases) e nossos pre-condicionamentos de predicção que são, de certa forma, consequência de nossos precondicionamentos para estimar coisas/bens/situações em termos opositivos de "muito grande x muito pequeno", "muito longo x muito curto" (estimation biases). (RESCHER, 2003).

${ }^{15}$ Rescher utiliza o termo paradoxo do prefácio em alusão ao autor que já se desculpa antecipadamente pelos equívocos que só serão posteriormente evidenciados quando da circulação do livro. O paradoxo decorre da verificação de que nosso metaconhecimento conflita com nosso conhecimento, exatamente porque embora tenhamos consciência de que nosso conhecimento é incompleto e falho, somos incapazes de, no futuro, identificar suas lacunas e equívocos, de forma a completa-lo ou corrigi-lo (RESCHER, 2003).
} 
Na medida em que a lógica se viu reduzida à lógica formal, a argumentação jurídica, com o propósito de não ser qualificada de reducionista, terminou por se afastar da utilização de métodos lógicos em geral, passando a ser moldada majoritariamente pela retórica.

Incorrendo no que Prakken (1997) nomeia de "incompreensões em relação à lógica", o Direito assumiu a equivocada premissa de que a lógica, enquanto estudo da correção formal do pensamento, exclui qualquer outra forma não dedutiva de argumentação.

Após relembrar que a lógica enquanto disciplina se debruça sobre o processo de construção de inferências, sejam elas dedutivas ou não (BELTRAN; RATTI, 2012), Sartor (2006) sustenta que há nítido espaço para sua aplicação no âmbito da argumentação jurídica, tanto para fins de justificação de proposições concretas factuais, quanto para fins da própria justificação das normas.

A partir da defesa da utilização, pelo Direito, de uma lógica não necessariamente dedutiva, apta a moldar esquemas argumentativos que operam com a inexistência e/ou inconsistência de informação, Sartor, Prakken e Schauer desenvolvem a ideia de derrotabilidade, enquanto fenômeno que só é viável na presença de esquemas de argumentação não conclusivos, submetidos à lógica de natureza não monotônica.

Nos esquemas regidos pela lógica não monotônica, a inserção de novas informações pode provocar uma reorganização das pré-condições da argumentação, o que faz com que seja impossível assegurar que as conclusões inicialmente obtidas possam ser mantidas no nosso cenário (SARTOR, 2012).

Diante das novas informações agora existentes, inferências que justificavam as primeiras conclusões podem simplesmente ter que ser afastadas - ou seja, derrotadas - sofrendo o processo que se denomina de rebutting, bem como podem ter sua força de justificação reduzida, em um mecanismo denominado de undercutting. As conclusões obtidas no âmbito da lógica não monotônica não são regidas pela ideia de preservação da verdade, própria da dedução, razão pela qual as conclusões obtidas são sempre apenas prováveis. É a lógica própria dos sistemas complexos, tais como a Inteligência Artificial, nos quais a que estrutura se reformula sempre que novas informações se tornam disponíveis.

No âmbito da interpretação jurídica, novas informações são disponibilizadas constantemente como fruto da interação dialética das partes, do juiz, do contexto, e elas têm a potencialidade de alterar eventuais inferências já realizadas. Assim, para Sartor e Prakken, o caráter dialético da argumentação, no âmbito da qual atuam interferem fatos, valores, contexto, demandaria a utilização, pelo Direito, de uma lógica não monotônica, compatível com sua 
natureza complexa e com a utilização da ideia de derrotabilidade, em detrimento da ineficiente dedução silogística.

\section{A UTILIZAÇÃo NÃO DOGMÁTICA dA DEDUÇÃO A PARTIR dA ÊNFASE NO ASPECTO PRAGMÁTICO: TENTATIVA DE COMPATIBILIZAÇÃO DO UNIVERSAL COM O PARTICULAR}

Não há dúvida de que a utilização dogmática da dedução silogística, largamente utilizada como instrumento da análise rule-centered, não é uma opção adequada ao âmbito do fenômeno jurídico. Ao universalizar o Direito em demasia, desvalorizando as particularidades do caso concreto, a concepção baseada na regra transforma-o artificialmente em um fenômeno raso e previsível, incompatível com sua real natureza. Opondo-se a ela, o particularismo defende que decisões versam "sobre situações específicas, concernem a pessoas particulares e são justificadas fazendo-se referência às circunstâncias do caso concreto" (TARUFFO, 2016, p.230).

Ambos os posicionamentos operam no extremo.

A crítica ao legalismo não pode conduzir à defesa de que uma decisão proferida a partir da adequada análise dos elementos do caso concreto não deva levar em consideração normas e princípios, podendo derivar da pura subjetividade do juiz (TARUFFO, 2016). Para se apartar do subjetivismo, "mesmo o tipo de decisão que parece estar mais diretamente vinculado aos fatos do caso concreto deve fazer referência a critérios generalizáveis, visto que requer a racionalidade global do sistema jurídico" (TARUFFO, 2016, p.231). Assim, fatos devem ser sempre qualificáveis com referência às normas aplicáveis.

Esta compreensão que aproxima em perspectiva dialética o universal do particular evidencia a necessidade de que o Direito adote um esquema argumentativo que, a despeito de não abandonar a lógica clássica, a utilize a partir de uma postura não dogmática, admitindo a existência de situações nas quais, ao ser submetida ao âmbito da pragmática, ela precisa dialogar com outras modalidades de lógica.

Na medida em normas gerais são pensadas para a maioria dos casos, mas são incapazes de prever toda e qualquer circunstância passível de realização no mundo concreto, é preciso admitir que uma norma jurídica pode, em situações excepcionais, deixar de ser aplicada, ainda que todos os elementos de seu antecedente normativo tenham se configurado, ante o reconhecimento da existência de uma cláusula de exceção que lhe é implícita. 
A exceção, consistente no afastamento da regra, "na verdade serve à regra, e não a prejudica, porque decorre da percepção de sua própria limitação (SARTOR, 2012).

Nesse sentido, "a operacionalização da regra é limitada em termos diferentes dos termos que suportam a regra em si mesma" (SARTOR, 2012, 10) e "isto confere certa estabilização ao fenômeno do Direito, embora não exclua a necessidade de que se abandone o próprio enunciado normativo, quando ele já não for mais capaz de refletir conexões normais, quando é ele próprio que é superado por informação subsequente" (SARTOR, 2012, p. 10).

Neste ínterim, o conhecimento da lógica não monotônica se torna relevante não para provocar o abandono absoluto do uso da dedução, que tem sua clara importância operacional, mas exatamente para complementá-la, passando a atuar sempre que ela se mostrar insuficiente, seja fins de solução dos denominados "casos difíceis ${ }^{16 "}$, seja diante de qualquer caso que, embora inicialmente considerado simples, se evidencie conflituoso ao longo do processo interpretativo.

\section{O FALIBILISMO E A CONSTRUÇÃO DA PREMISSA EPISTEMOLÓGICA PARA A APLICAÇÃO ARGUMENTATIVA DA NOÇÃO DE DERROTABILIDADE}

Assentada sob o ponto de visto lógico na "não monoticidade", no âmbito da perspectiva epistêmica a derrotabilidade encontra sua fundamentação no pensamento falibilista.

A adoção do pensamento falibilista desvincula o caráter científico da utilização do método dedutivo, passando a condicioná-lo à (in) existência de uma postura científica de criticidade que admite a perspectiva do erro.

A ideia subjacente ao falibilismo manifesta-se no Direito muito antes da noção de derrotabilidade de normas, na medida em que já se mostra presente em momento anterior, qual seja o da determinação de seu sentido, ou do sentido do texto que as enuncia. É que um texto pode parecer existente, parecer válido, parecer em vigor, mas o será apenas até que se demonstre o contrário. Seu sentido pode parecer ser " $x$ ", em um primeiro momento, e depois se revelar “y”, ainda que sem que para esta mudança seja necessária a realização de qualquer ponderação.

Em um cenário no qual o Direito é concebido a partir desta perspectiva falibilista, admite-se a possibilidade de que se tenha "primeiras impressões" sobre algo, mas que elas

\footnotetext{
${ }^{16}$ Segundo Conrado Hubner Mendes (2008, p. 34), em sua tese de doutorado, “casos difíceis” são os que despertam as grandes divergências nas teorias da interpretação, pois não correspondem aos momentos em que a norma não é suficiente para constranger o juiz"
} 
possam ser retificadas a partir de novas análises (do texto, da situação de fato a ser por ele disciplinada, das consequências a serem alcançadas, dos valores a serem prestigiados), de modo que tais impressões nunca são realmente completamente definitivas. É possível que o sejam no âmbito do processo específico, no qual se viabiliza a solução do conflito em virtude da necessidade imposta pelo tempo e pela concretização de alguma segurança jurídica, mas não o serão no plano filosófico ou científico ${ }^{17}$.

O reconhecimento permanente da possibilidade do erro e a ideia de refutação que dele decorre - ou seja, a falibilidade - está na raiz da noção de derrotabilidade.

A despeito da falta de univocidade do conceito, a derrotabilidade parte da concepção de que, mesmo quando as condições do antecedente normativo se apresentam preenchidas, normas jurídicas, porque consideradas objetos de discurso, não têm que ser necessariamente aplicadas, como o eram no âmbito do dedutivismo ingênuo, podendo ter sua aplicabilidade afastada no caso concreto (serem, portanto, refutadas), ante a perspectiva de que sua aplicação provocaria um defeito sistêmico. É possível afirmar haver na derrotabilidade um núcleo comum “consistente na ideia segundo a qual a consequência da norma jurídica pode ser derrotada, afastada, não-aplicada, em razão da existência de um fato, interpretação ou circunstância com ela incompatível" (VASCONCELLOS, 2009, p. 51).

Assim, embora teoricamente adequadas, normas jurídicas podem se evidenciar defeituosas no bojo de sua utilização prática, porque incompatíveis com as razões que as justificaram, de modo que, se aplicadas, provocam incoerência e inconsistência no sistema do Direito. Nessa circunstância, reconhecer o defeito e afastar a norma é, sob o ponto de vista lógico, ato de preservação da própria estrutura que, diante da mudança do contexto provocada pela superveniência de informação antes inexistente, se adapta.

Concebida nesses termos, a derrrotabilidade é pura aplicação argumentativa das premissas do pensamento falibilista.

Em Popper, a nota distintiva da ciência se evidencia na utilização, pelo cientista, de um método crítico, assentado na adoção de uma postura voltada para a obtenção de refutação das

\footnotetext{
17 Talvez um Hércules conseguisse chegar a uma resposta correta e definitiva, mas o magistrado que decide os dilemas reais encontrará tão somente uma resposta potencialmente e provisoriamente correta. Essa metáfora de Dworkin tem sido mal compreendida por alguns autores. Talvez o que Dworkin esteja dizendo não é que os juízes devam ter características super-humanas, o que se sabe impossível, mas que existe sim uma solução correta, que se for procurada pode ser encontrada, tanto que um "hércules" a encontraria, a despeito da dificuldade humana em dela se aproximar, em virtude dos inúmeros vícios e obstáculos inerentes ao conhecimento. Afasta-se, assim, concepções de cunho ceticista, que defendem inexistir esta verdade, tornando admissível um leque de "soluções corretas", todas igualmente válidas, como fazem algumas correntes positivistas.
} 
teorias existentes e, como decorrência, de contínua geração de novos problemas e novas teorias dotadas de maior caráter informativo, dentro de um cenário no qual teorias competem pela "preferência" (POPPER, 2001).

Popper sustenta que todo ser vivo utiliza a sistemática de tentativa e erro quando se depara com um problema que lhe ameaça a sobrevivência e tende, então, a buscar a homeostase $^{18}$, promovendo as adaptações necessárias à sua obtenção. A partir de movimentos de experimentação, ele faz surgir expectativas de solução para o problema que, se frustradas, lhe conduzirão a morte.

Assemelhando as “expectativas” dos seres vivos às teorias/hipóteses, Popper afirma que a diferença fundamental entre o conhecimento pré-científico e o que denominamos de ciência é que no conhecimento pré-científico a eliminação do problema é algo que "nos acontece", do qual o agente cognoscente é observador passivo, ao passo que no conhecimento científico o cientista deixa de evitar a refutação para na verdade deseja-la.

$\mathrm{Na}$ ciência, o agente se transforma em ativo questionador das ideias propostas e, guiado pela ideia de refutação, procura inclusive conformar o ambiente a sua volta para que ele se torne tão hostil quanto possível à solução contingencialmente existente, porque a eventual refutação deste conhecimento e sua substituição por um novo é recebida como aproximação da verdade. Desta forma, "todo o conhecimento pré-científico, animal ou humano, é dogmático; e a ciência começa com a invenção do método crítico não dogmático" (POPPER, 2001, p.22)

Aplicado o falibilismo ao conceito de derrotabilidade, é possível perceber a nítida relação. A derrotabilidade, assentada na provisoriedade do conhecimento e na necessidade de sua adaptação, utiliza o método crítico, tal como delimitado por Popper. Visualiza o ordenamento jurídico como um sistema não completo e mutável, em constante interação com o ambiente que o circunda, e que precisa a ele se moldar, no âmbito do caso concreto, quando da construção interpretativa da norma jurídica, para solucionar eventuais problemas que fragilizem sua coerência.

É, portanto, postura que se contrapõe diretamente ao dedutivismo ingênuo decorrente da utilização, no Direito, da lógica formal clássica em uma perspectiva estritamente dogmática.

A dogmática jurídica não costuma aceitar a situação consoante a qual o fato previsto no antecedente de uma norma jurídica ocorre e a previsão do consequente não é atendida, sem que nenhuma sanção, como decorrência, seja cominada. A doutrina, em circunstâncias como estas,

\footnotetext{
${ }^{18}$ Denomina-se homeostase o processo de busca pelo estado de equilíbrio na qual cada ser vivo tem garantido os parâmetros necessários à manutenção da vida (DAMÁSIO, 2011).
} 
costuma falar em perda da eficácia ou em descumprimento legal, e é incapaz de lidar com o fenômeno que ocorre rotineiramente na prática (VASCONCELLOS, 2009).

A teoria da derrotabilidade surge exatamente para tutelar essas situações, para as quais a dogmática tradicional não consegue dar $\operatorname{respostas}^{19}$. Enquanto a dogmática tradicional visualiza o texto do enunciado jurídico sob as perspectivas sintática e semântica, a derrotabilidade se volta ao aspecto pragmático.

Desta forma, "uma regra jurídica que expressa uma obrigação prima facie não exclui a possibilidade de que situações não contempladas cancelem o dever estabelecido na regra" (VASCONCELLOS, 2009, p. 55), o que faz com o enunciado normativo mantenha o seu caráter prescritivo, mas possa ser eventualmente derrotado ante as circunstâncias do caso concreto.

Derrota-se, portanto, a norma jurídica em uso, e nunca o próprio enunciado.

\section{OS LIMITES DA CLÁUSULA IMPLÍCITA DE EXCEÇÃO: NORMAS COMO MOLDURAS ARGUMENTATIVAS}

Quando conceituada nestes termos, a derrotabilidade é criticada sob o argumento de que legitima decisões contra legem. Segundo Samuel Fonteles (2016, p. 63), "esse é o perigo da derrotabilidade das regras: sua aplicação metotodológica quase sempre se dá ao arrepio do Direito posto, desaguando em decisões judiciais contra legem".

A crítica merece comentário.

De início, é importante diferenciar a decisão contra legem do decisionismo, fenômeno lesivo ao Direito e que não é legitimado pelo instituto da derrotabilidade. A derrotabilidade não ampara o decisionismo exatamente porque propicia o afastamento da norma dentro de um contexto argumentativo modulado pela lógica, no bojo do qual a argumentação jurídica é concebida como uma cadeia de garantias, na qual inferências devem ser sustentadas e podem ser refutadas. Esta perspectiva amplia a segurança e o grau de controle, que é muito menos eficiente no espaço da retórica.

É preciso perceber que a aceitação da derrotabilidade no exercício da argumentação jurídica encontra limites nas suas próprias premissas. Para melhor compreensão deste aspecto, adquire relevância a análise do pensamento de Frederic Schauer.

\footnotetext{
${ }^{19} \mathrm{E}$ isto comprova a afirmação feita no início deste texto no sentido de que embora a visão que se denomina de estritamente dogmática já não corresponda necessariamente a forma como o Direito é atualmente pensado, ela ainda está espalhada, em maior ou menor grau, tanto no âmbito da construção do ordenamento jurídico, quanto em sede de sua aplicação.
} 
A partir da diferenciação das regras ${ }^{20}$ em descritivas e prescritivas, Schauer (1991) defende que as regras prescritivas são construídas com o nítido propósito de regular as condutas humanas, de gerar pressão sobre o mundo, o que faz com que, por natureza, elas devam reagir às tentativas de serem afastadas. É que se qualquer senso de injustiça ou a formação de qualquer opinião contrária por parte do julgador pudesse justificar a não aplicação de uma norma, então não haveria nenhuma diferença entre um regime de normas que admita a derrotabilidade e a inexistência de qualquer regime.

Desta forma, a premissa inicial da construção de seu raciocínio é a de que regras jurídicas não são foram feitas para serem rotineiramente derrotadas quando da verificação da ocorrência de seus antecedentes, mas, ao contrário, devem resistir a esta tentativa (SCHAUER, 1991).

No entanto, toda regra, prescritiva ou não, é indubitavelmente uma generalização da realidade, o que lhe confere uma natureza contingente. Ao tentar modular a complexidade do mundo, ela realiza um processo de seleção e supressão, a partir do qual identifica o que considera serem as características fundamentais da situação que intenciona regular, da particularidade a que se direciona. Na medida em que a regra é construída com um propósito, é a sua justificação - sua ratio essendi - que direciona os critérios dessa seleção. A justificação da norma deve fazer com que seja possível estabelecer uma relação probabilística entre o seu predicado fático e a ocorrência de eventos no mundo (SCHAUER, 1991).

O conhecido exemplo da proibição da entrada de cachorros no restaurante explica a lógica do raciocínio. Tome-se a norma "cachorros são proibidos" exteriorizada em uma placa na porta de um restaurante. A formulação da norma, ao se utilizar da dicção "cachorro", se limita a selecionar o que considera essencial para a identificação do objeto a que se direciona, suprimindo qualquer outra característica (raça, cor, tamanho) que considera irrelevante e tem por justificativa a crença de que, normalmente - e esta é a palavra-chave - a entrada de cachorros poderia perturbar os clientes que estejam no ambiente. Mas nem todo cachorro necessariamente gerará a perturbação que a norma pretendia evitar, ao mesmo tempo em que outros animais podem também provocá-la. Normas são gerais, mas não são universais.

A partir dessa percepção, Schauer constrói os conceitos de sobreinclusão e subinclusão.

\footnotetext{
${ }^{20}$ Utiliza-se o termo regras e não normas porque em Playing by the rules Schauers trata das normas jurídicas que prescrevem condutas, diferenciando-as das regras descritivas. Assim, ele confere tratamento ao que comumente denominamos de regras, em sua diferenciação em relação aos princípios que, na esteira da teoria de Alexy, não prescrevem condutas, porquanto constituem mandamentos de otimização.
} 
Por serem contingentes, regras podem terminar incorporando "mais casos do que deveriam ou deixarem de incorporar casos que deveriam incorporar para concretizar as suas justificações, o que torna o Direito, ou melhor, a prática jurídica, um terreno de escolhas" (STRUCHNER, 2010, p. 49).

Como consequência, regras podem ser derrotadas no âmbito do caso concreto não em função do subjetivismo do julgador, mas quando - e somente quando - seu afastamento ou a ampliação de seu espectro de aplicabilidade sejam necessários para que se assegure a preservação da relação entre o seu predicado fático e sua justificação.

Regras "se racionalmente justificáveis, resultam da ponderação de princípios" (BUSTAMANTE, 2010, p. 156), de modo que a regra "nunca perde completamente o contato com os princípios que se escondem por detrás dela" (BUSTAMANTE, 2010, p. 157), conservando com eles uma ligação.

Nesse sentido, se toda regra se vincula a um princípio que fundamenta sua razão de ser, há razoabilidade na conclusão de que deve ser aplicada quando se verifica, de forma segura, que essa razão de ser não teria tido prioridade no âmbito do caso concreto acaso fosse possível, ao legislador, ao tempo da feitura da regra, tomar conhecimento de certas particularidades que não foram e não puderam ser por ele antecipadamente conhecidas (BUSTAMANTE, 2010)

Thomas Bustamante sintetiza os requisitos que justificam a prolação da decisão a que se denomina de contra legem nos seguintes termos:

\begin{abstract}
Uma decisão contra legem pode ser definida como uma decisão que estabelece uma exceção a uma norma jurídica $\mathrm{N}$, na presença das seguintes condições: (i) $\mathrm{N}$ é uma norma do tipo regra, e não um princípio jurídico; (ii) $\mathrm{N}$ está expressa em uma lei ou outra fonte formal do direito com igual nível hierárquico; (iii) os significados mínimos ou literais das expressões utilizadas pelo legislador não permitem extrair do texto que serve de base a $\mathrm{N}$ uma norma alternativa que não seja contrariada por tal decisão; (iv) a decisão não reconhece a invalidade de $\mathrm{N}$, mas apenas afasta a sua aplicação a uma situação em que ela é aplicável; (v) não há dúvida de que os fatos que deram origem à decisão podem ser subsumidos em $\mathrm{N}$; (vi) a autoridade que adota essa decisão estabelece uma norma individual formulada em termos universais; e (vii) a decisão levanta uma pretensão de juridicidade para essa norma individual (BUSTAMANTE, 2010, p. 174)
\end{abstract}

No entanto, na medida em que apresentam eficácia de trincheira, regras só podem ser derrotadas em circunstâncias absolutamente excepcionais, as denominadas situações recalcitrantes. Para além disso, a norma individual que deriva da utilização da derrotabilidade tem de apresentar as suas conclusões "como emanando de uma regra que pode ser generalizada e deve ser repetida em todos os casos semelhantes, sob pena de séria violação aos princípios gerais da imparcialidade e da justiça formal” (BUSTAMANTE, 2010, p. 175). A exigência da 
presença de fundamento universal na norma individual é exatamente o que distingue a derrotabilidade normativa do subjetivismo e do decisionismo.

A vinculação ao princípio de que a regra decorre, o respeito pela sua justificativa e pela existência de um mínimo sentido de linguagem que não está à disposição do intérprete instrumentam o controle que deve ser exercido, dentro do jogo argumentativo, com o propósito de evitar que derrotabilidade seja utilizada de forma inadequada.

Toda norma jurídica, seja regra ou princípio, é, por natureza uma moldura argumentativa, no âmbito da qual "tudo deve ser considerado" (all things considered).

O reconhecimento da existência de distinção entre o texto normativo e a norma como juízo hipotético permite compreender que é no âmbito da norma hipotética como moldura argumentativa que acontece o debate interpretativo no qual, via argumentação, princípios e regras são confrontados com o contexto, gerando, como consequência, a norma individual e concreta $^{21}$.

Essa percepção permite defender a plena possibilidade de ponderação do que usualmente denominados de regras, ante a compreensão de que essa sua natureza não se encontra estipulada ex ante no âmbito do texto, mas é encontrada exatamente na fase de ponderação, a partir do contexto e do caso no qual se dará a aplicação.

\section{AS TRÊS FACES DA DERROTABILIDADE NO DIREITO: NOÇÕES GERAIS}

Mas a derrotabilidade atua na argumentação jurídica a partir de diversas vertentes.

A consciência de que Direito é um fenômeno complexo ${ }^{22}$, exige que a derrotabilidade seja analisada a partir da conjunção das suas perspectivas estática e dinâmica.

De acordo com Henry Prakken e Giovanni Sartor (2004) é possível identificar três faces da derrotabilidade no Direito, podendo ela decorrer do estabelecimento de relações de natureza distintas entre duas ou mais inferências, quando será denominada de inference-based (baseada na inferência), resultar da incidência de regras procedimentais no âmbito do processo judicial, ocasião em que é chamada de processed-based (baseada no processo), ou, ainda, ser visualizada

\footnotetext{
${ }^{21}$ Percebido o fenômeno desta forma, torna-se também possível defender a ocorrência de derrotabilidade no que concerne a princípios, visão rechaçada por alguns em virtude de sua natureza de mandamentos de otimização, a partir da defesa de que, na arena da argumentação, toda opção por uma interpretação significa a derrota de outra. Princípios entendidos como argumentos podem, portanto, serem derrotados.

${ }^{22}$ Utiliza-se o termo complexidade nos termos em que definido pela teoria da complexidade, já mencionada neste artigo.
} 
quando da refutação da teoria em si mesma que rege a seara do jogo argumentativo, no bojo de uma derrotabilidade theory-based (baseada na teoria) (PRAKKEN; SARTOR, 2004).

A primeira delas, a denominada derrotabilidade inferencial, se desenvolve a partir dos elementos do rebutting e do overcutting.

A derrotabilidade inferencial é um "problema de qualificação", assim compreendida a dificuldade de determinar se um fato está ou não inserido dentro do campo de aplicação de um conceito.

O problema de qualificação é uma lacuna do conhecimento, uma evidente decorrência da incompletude e da natureza falha do conhecimento humano, que faz com que o agente cognoscente sempre construa sua conclusão, sempre provisória, a partir do insuficiente volume de informações disponíveis no momento.

Como é impossível exigir do intérprete que adote determina conduta ou forme sua convicção apenas após checar todas as condições necessárias (all things considered) para fins de certeza do sucesso ou da verdade, o raciocínio se desenvolve, na prática, a partir de modelos que se baseiam em "saltos" lógicos em direção a determinadas conclusões que nada mais são do que o fruto da articulação entre as razões e as contrarrazões então existentes.

No entanto, a conclusão inicialmente obtida, denominada por Sartor (2012) de crença pro tanto - aquela possível em função do volume de informação disponível-, pode ter que vir a ser posteriormente revista em função do "rebatimento" da inferência na qual se sustentava quando do acréscimo de novas informações no sistema não monotônico.

A informação acrescida pode reorganizá-lo de modo a que uma nova inferência, antes inexistente, colida de forma incompatível com a anteriormente utilizada para fins de justificação da conclusão adotada. Nessa circunstância, a adoção da nova inferência importará necessariamente no abandono da anterior, porque rebatida pela superveniente o que, por sua vez, torna absolutamente impossível a manutenção da conclusão originária (PRAKKEN; SARTOR, 2004).

Trata-se do fenômeno denominado de rebutting.

Imagine-se a situação na qual se chega à conclusão de que Ana matou João com base no testemunho de Silvia, que é posteriormente questionado por Maria, que sustenta ser outro o assassino. Adotada a nova inferência decorrente da superveniência do testemunho de Maria, será preciso desconsiderar o testemunho de Silvia, porque com ele incompatível, o que alterará a conclusão inicial, fazendo com que se passe a concluir pela inocência de Ana.

No entanto, é possível que a inferência superveniente não seja completamente incompatível com a anteriormente utilizada e desta forma não a afaste de forma absoluta, mas 
tão somente enfraqueça sua credilibilidade. Neste caso, opera-se o que a derrotabilidade denomina de undercutting, a ocorrência de um corte, uma redução na força de justificação da inferência.

Adotando-se o mesmo exemplo, no qual Ana foi considerada culpada pela morte de João com base no testemunho de Silvia, estar-se-ia em situação de undercutting se, posteriormente, o intérprete adquirisse a informação de que o testemunho de Silvia havia sido comprado.

Embora não seja possível afastar completamente a tese de que Ana matou João pela superveniência da nova informação, sua inserção no jogo argumentativo retira a credibilidade do testemunho de Silvia, diminuindo sua importância enquanto justificativa para a conclusão inicial que então, para que se sustente, deverá procurar se fundamentar concomitantemente em outras inferências, aumentando seu grau de força.

A ideia central no âmbito da derrotabilidade inferencial é a de que a argumentação jurídica deve ser concebida como uma cadeia de garantias, com antecedentes justificando consequentes. Eventuais conflitos entre inferências devem ser solucionados pela priorização da inferência mais sólida, aquela que apresenta maior garantia, no âmbito de um modelo de argumentação legal que se desenvolve a partir da interação dialética das inferências em competição (PRAKKEN; SARTOR, 2004).

É com base nesta lógica de derrotabilidade que Stephen Toulmin construiu o seu modelo argumentativo, voltado a funcionar como um instrumento que faça com que argumentos possam ser criados a partir de uma estrutura formal e depois avaliados, conforme o seu grau de força, a partir dos parâmetros desta mesma estrutura.

A estrutura se inicia com a definição do que constitui a alegação (claim), entendida como aquilo que se pretende defender racionalmente, a conclusão do raciocínio.

O modelo se constrói a partir da previsão de que toda alegação se sustenta concomitantemente em dados e em outro elemento, por ele denominado de garantia (warrant), que estabelece a natureza do vínculo entre o dado referido como base do raciocínio e a alegação que foi apresentada como conclusão (MAIA, 2014).

No caso do Direito, essa garantia é, via de regra, a existência de um enunciado legal. A garantia, por sua vez, é ao mesmo tempo amparada pelo que a estrutura denomina de backing e excepcionada pelo que ela denomina de rebuttal, elemento que alude a uma regra de exceção, nos termos da qual a garantia, que normalmente deve ser aplicada, pode eventualmente ser derrotada. A previsão simultânea do backing e do rebuttal denota o caráter dialético da argumentação. Por fim, a força da conclusão, identificada após sua submissão ao espaço 
argumentativo da estrutura, é exteriorizada através do elemento denominado de qualifier (MAIA, 2014).

A formalização lógica do fenômeno da argumentação jurídica tem por propósito afastar o decisionismo e o psicologismo, possibilitando o questionamento e eventual refutação das conclusões obtidas a partir da análise de sua força, à luz da contraposição entre as inferências que as confirmam e as que a rechaçam.

No entanto, nem toda inferência é derrotada logicamente.

É possível que uma inferência seja "derrotada" não porque foi logicamente rebatida por uma inferência que lhe é posterior, mas simplesmente porque a evidência que lhe sustentava foi considerada inadmissível por uma regra formal do processo legal.

Trata-se da derrotabilidade baseada no processo.

Segundo Prakken e Sartor (2004), é importante perceber que a análise da derrotabilidade tão somente a partir da perspectiva inferencial se torna limitada porque não leva em consideração os aspectos dinâmicos impostos à argumentação jurídica pelas normas de procedimento. Ignora-se a existência de elementos que, embora não sejam lógicos, afetam substancialmente a manutenção ou a derrotabilidade de uma inferência e, por consequente, da conclusão que nela se justifica (PRAKKEN, SARTOR, 2004).

A maneira a partir da qual o processo legal valora o ônus da prova, o efeito da disputa, o acatamento ou afastamento de um argumento, a admissibilidade de uma evidência ou de uma contraprova e a força probatória das evidências afeta sobremaneira a ocorrência ou não de derrotabilidades processualmente mediadas.

Por fim, para além da derrotabilidade que opera dentro do jogo argumentativo é possível conceber uma terceira modalidade de derrotabilidade que ocorre no âmbito da epistemologia, denominada de derrotabilidade baseada em teorias. Nesse sentido, uma teoria jurídica pode ser refutada, de forma total ou parcial, quando da superveniência de uma nova, que deve prevalecer sobre a anterior por se mostrar mais apta a abarcar um maior volume de casos, maior amplitude de valores, apresentar maior conectividade analógica e menor ou nenhuma arbitrariedade (PRAKKEN, SATOR, 2004).

Evidenciadas as três faces da derrotabilidade no Direito, cumpre traçar mais alguns comentários acerca da derrotabilidade processual, ante a relevância que sua utilização pode adquirir na seara judicial para fins de instrumentar a obtenção da verdade no processo.

\section{A UTILIZAÇÃO DA DERROTABILIDADE NO ÂMBITO DO PROCESSO COMO INSTRUMENTO DE ENUNCIAÇÃO DA VERDADE.}


Quando aplicada no âmbito judicial, a derrotabilidade se relaciona diretamente com a questão da prova, dotada de caráter instrumental na busca pelo estabelecimento da verdade processual. Adotada a premissa de que o processo deve ter por objetivo produzir decisões justas, é preciso reconhecer que independentemente do conceito de justiça que se adote uma decisão nunca será justa "se está fundada em uma determinação errônea ou inaceitável dos fatos" (TARUFFO, 2009, p. 64).

É sobre fatos que as normas jurídicas são aplicadas, razão pela qual uma incorreta ou inadequada produção e/ou apreciação do conjunto factual conduz necessariamente a uma decisão menos justa, ou até mesmo injusta.

A verdade obtida no âmbito do processo é, obviamente, a verdade possível, aquela produzida a partir das limitações que lhe são impostas pelos instrumentos cognoscitivos disponíveis, pelo tempo, pelas capacidades humanas e pelas normas jurídicas. É também a verdade que se obtém enquanto fruto do contexto, a partir dos conjuntos de pressuposições, conceitos, noções, regras e marcos de referência estabelecidos por um determinado ordenamento, a partir dos quais se constroem as versões dos fatos (TARUFFO, 2009).

Mas a característica relativa desta verdade não significa que ela não exista e não deva ser buscada nos autos. Buscar a verdade, por sua vez, significa determinar dentro de uma perspectiva racional e dialética a quem compete provar os fatos, como eles devem ser provados e como devem ser apreciados pelo magistrado. Mas significa, para além disso, pensar o processo como um contexto apto à aplicabilidade da lógica derrotável, no bojo do qual a inclusão de novas informações provoca, ainda que potencialmente, a reorganização do sistema, podendo conduzir a novas conclusões.

\subsection{Derrotabilidade e ônus probatório}

No âmbito do processo, a derrotabilidade pode ser utilizada para modular o mecanismo de atribuição do ônus da prova e de sua apreciação, o que impacta diretamente a definição da verdade refletida na decisão final.

Sartor e Prakken (2006) evidenciam existirem no processo enquanto relação dialógica três espécies de ônus, quais sejam o ônus de persuasão, o ônus de produção e o denominado ônus probatório tático.

O ônus de produção impõe a quem faz uma alegação a tarefa de prover um argumento que a justifique. Ao reclamante cabe provar os denominados fatos operacionais da alegação, 
assim entendidos os fatos que constituem, de acordo com a lei, razão suficiente para o acolhimento do pleito por ele formulado. No modelo proposto por Sartor e Prakken, os fatos operacionais se assemelham ao que Toulmin denomina, em sua estrutura, de "dados 23 ".

A depender do sistema legal e do âmbito do Direito, o ônus de persuasão pode impor à parte o dever de persuadir em graus de força distintos, tais como a exigência de excluir qualquer dúvida razoável ou propiciar evidência preponderante. O ônus de persuasão, por definição, é sempre do reclamante (SARTOR; PRAKKEN, 2006)

Para o reclamado surge o ônus de produção, nos termos do qual lhe compete afastar ou ao menos diminuir a força probatória das evidências apresentadas pelo reclamante, promovendo, como já visto ao longo do presente texto, rebutting ou undercutting na inferência até então existente. Assim como o ônus de persuasão é do reclamante, o ônus de produção também é fixo ao longo do jogo dialógico, sendo imposto ao reclamado (SARTOR; PRAKKEN, 2006)

Há, por fim, um terceiro ônus da prova, este de natureza dinâmica, exteriorizado no denominado ônus probatório tático, que se alterna entre reclamante e reclamado reiteradamente durante processo. O ônus de prova tático consiste na necessidade de que cada parte avalie, de forma contínua ao longo de todo o embate argumentativo, o risco de perder um determinado aspecto do litígio acaso não produza nenhuma outra evidência referente a este aspecto.

O ônus tático requer que cada uma das partes pondere reiteradamente a força probante das evidências que apresentou enquanto conjunto inferencial apto a fundamentar o acolhimento da alegação, no caso do reclamante, ou sua negativa, no caso do reclamado (SARTOR; PRAKKEN, 2006).

Encerrado o primeiro estágio no qual o reclamante põe fim ao seu ônus de persuasão e o reclamado ao seu ônus de produção, cada apresentação de nova evidência por cada uma das partes termina por impor à outra o ônus probatório tático que, ao ser invertido, faz com que o opositor tenha que reexaminar a força das evidências já apresentadas, de modo a decidir acerca da pertinência ou não da apresentação de novas provas (SARTOR; PRAKKEN, 2006).

No entanto, embora o denominado ônus da prova global seja estabelecido pela legislação, via de regra, apenas na fase do confronto, Douglas Walton (2005) enfatiza a necessidade de que sejam encontrados mecanismos aptos a solucionarem as disputas referentes ao estabelecimento do ônus da prova ao longo de todo o percurso argumentativo, tal como na

\footnotetext{
${ }^{23} \mathrm{O}$ modelo Toulmin foi explicado brevemente no tópico 7, no âmbito da definição da derrotabilidade inferencial.
} 
fase de argumentação e também no estágio final da conclusão, o que poderia ser proporcionado por modelos de metalinguagem.

Sendo o processo um contexto no qual cada nova evidência apresentada por qualquer das partes pode modificar as premissas decisórias, a produção e a avaliação das provas, a argumentação jurídica assume um caráter eminentemente não monotônico, razão pela qual, segundo Sartor e Prakken (2006), poderia se beneficiar de modelagens formais desenvolvidas para fins de tratamento de esquemas derrotáveis, como as utilizadas no âmbito da Inteligência Artificial.

Por fim, na seara da esfera probatória, adquire importância o instituto da presunção, ao afetar diretamente a avaliação da prova.

A presunção é um recurso procedimental que viabiliza a tomada da decisão, no âmbito do qual não há preocupação com a verdade dos fatos, mas sim com a viabilização da continuidade do julgamento do caso posto em análise. Por esta razão, a norma de presunção tem natureza contra epistêmica, ao afastar a decisão judicial da análise dos fatos e fazer com que deles se ocupe somente quando prova contrária for fornecida.

No jogo argumentativo, a invocação da presunção permite que a parte, mesmo sendo incapaz de disponibilizar evidência, preencha a materialidade do ônus de persuasão, no caso do reclamante, ou do ônus de produção, no caso do requerente, ao mesmo tempo em que impõe sobre o adversário o ônus de prova tático. A inversão do ônus tático decorre da constatação de que a presunção nada mais é que uma inferência e como tal, por natureza, também é passível de refutação (SARTOR; PRAKKEN, 2006)

A aplicação da ideia de derrotabilidade ao âmbito argumentativo do processo impõe o reconhecimento de que, por ser a presunção mera estimativa provisional dos fatos, ela não é completamente segura até que seja derrotada, razão pela qual deve ser afastada se e quando as questões relevantes ainda não clarificadas o forem (RESCHER, 2006).

\subsection{A Derrotabilidade e o dever de motivação das decisões judiciais}

Sob a ótica do magistrado, um processo regido pela ideia de derrotabilidade exige do juiz a compreensão de que a decisão judicial deve ser "resultado de um procedimento racional, que se desenvolva segundo regras e princípios, ou seja, segundo um método que permita seu controle e determine sua validade" (TARUFFO, 2016, p.224).

Essa perspectiva afasta o dever de motivação das decisões judiciais do âmbito da pura retórica e do psicologismo e o aproxima da seara da lógica, utilizada como instrumento para modelar a seara da argumentação jurídica. 
Assim, dele não se requer a reprodução da sequência de pensamentos e de estágios psicológicos o conduziram à construção da decisão, o que seria de todo impossível. Em função do dever de motivação, cumpre-lhe exteriorizar, no bojo da decisão, justificação completa e coerente acerca dos fatos, tornando possível a identificação, pelas partes, de eventuais inconsistências lógicas e argumentativas.

É que apenas tendo acesso à justificação adotada pelo julgador no que concerne aos enunciados que dizem respeito aos fatos da causa as partes poderão eventualmente refutar as conclusões da decisão final de forma racional e lógica (TARUFFO, 2016), mediante a constatação de circunstâncias de rebutting e overcutting que, embora por ele não percebidas, possam enfraquecer ou até mesmo inviabilizar a conclusão adotada.

Ao realizar de forma adequada a sua função, o juiz consegue excluir a percepção de que a decisão judicial é somente "um discurso retórico-persuasivo, tendo o fim não de justificar racionalmente a decisão, mas sim de convencer alguém a aceitá-la” (TARUFFO, 2016, p.273).

Para cumprir este desiderato, deve se preocupar em construir a sua narrativa em quatro níveis, o que o permitirá ser capaz de estabelecer correlação entre os diversos conjuntos ordenados de enunciados que descrevem as modalidades e as circunstâncias relativas aos fatos que originaram a controvérsia (TARUFFO, 2016).

Aos fatos principais ( $1^{\circ}$ nível), deve acrescentar a detida análise dos fatos secundários ( $2^{\circ}$ nível), dos enunciados que resultam da análise das provas produzidas nos autos ( $3^{\circ}$ nível), e das circunstâncias que conferem credibilidade às provas que foram apresentadas ( $4^{\circ}$ nível). Tem por tarefa, então, construir ligação inferencial entre eles, de modo a se tornar apto a estabelecer a justificação de suas conclusões através da utilização de critérios de inferência, que levem em consideração "a quantidade e a qualidade das provas disponíveis que se referem àquele enunciado, seu grau de confiabilidade e sua coerência" (TARUFFO, 2016, p. 253).

O juiz formula ligações entre fatos, provas e warrants, aqui compreendidos como os elementos que conectam provas aos fatos descritos nos enunciados, em uma dinâmica muito compatível com o modelo desenvolvido por Stephen Toulmin, já mencionado neste artigo.

A partir do maior ou menor grau de confirmação que o enunciado recebe a partir deste procedimento, o julgador deve produzir uma decisão final que seja fruto de uma relação dialética, ciente de que "o valor de verdade dos juízos que ele faz depende diretamente do fundamento racional cognoscitivo das inferências de que tais juízos derivam. Quanto mais aprofundada a análise crítica das noções que o juiz emprega, mais confiáveis são as inferências probatórias que levam à confirmação das hipóteses sobre os fatos" (TARUFFO, 2016, p.242). 
As provas devem ser admitidas e valorizadas sob um ponto de vista rigorosamente analítico, segundo o qual todo e qualquer fato relevante, seja principal ou secundário, deve ser objeto de apuração específica, havendo a preocupação, ainda, de produção, sob a ótica global, uma narrativa coerente.

Neste contexto, uma decisão que adota motivação implícita, motivação per relationem ou faz mera referência às provas, sem promover sua análise efetiva, é uma decisão que descumpre o seu dever de motivação e que por isso lesa às partes, na medida em que impede a utilização da derrotabilidade como instrumento lógico-argumentativo que evidencie a fragilidade da conclusão obtida.

Incorre também em descumprimento do dever de motivação a decisão que fundamenta a escolha de uma prova como critério de inferência para a conclusão formulada sem, no entanto, evidenciar as razões pelas quais as demais provas existentes nos autos foram rechaçadas.

À luz do preceito constitucional de motivação, "o juiz deve justificar a sua opção por aceitar como verdadeira uma entre várias alegações controvertidas sobre os fatos relevantes" (GUERRA, 2010, p. 08), o que pressupõe externar as razões pelas quais conferiu maior força probatória a uma proba específica em detrimento das demais.

Apenas assim, quando a motivação dos fatos é completa e coerente, de modo que "a narrativa dos fatos construída pelo juiz é dotada de uma justificativa racional válida já que confirmada pela análise crítica de todas as provas disponíveis" (TARUFFO, 2016, P. 278), torna-se possível dizer que a decisão enuncia a verdade.

\section{CONCLUSÃO}

A partir do que restou exposto ao longo do presente artigo, é possível concluir que:

a) A lógica clássica é insuficiente para lidar com o complexo sistema jurídico, caracterizado por emergência, vagueza, ambiguidade, incompletude e inconsistência de informações; enquanto o método dedutivo formula conclusões que decorrem da necessária aceitabilidade das premissas estabelecidas, o problema do Direito está propriamente na (in) aceitabilidade das premissas utilizadas para fins de decisão, razão pela qual as decisões jurídicas não precisam ser deduzidas, mas sim justificadas; A argumentação jurídica se assemelha aos sistemas regidos pela lógica não monotônica, no âmbito dos quais a inserção de novas 
informações não raras vezes provoca uma reorganização das pré-condições da argumentação, tornando impossível assegurar a manutenção das conclusões inicialmente obtidas;

b) Esta natureza dinâmica impõe a adoção de um esquema argumentativo que, a despeito de não abandonar completamente a lógica dedutiva, a utilize a partir de uma postura não dogmática, admitindo haver situações nas quais, ao ser submetida ao âmbito da pragmática, ela tenha que dialogar com outras modalidades de lógica para solucionar os casos concretos;

c) A adoção epistemológica do pensamento falibilista no âmbito da Teoria do Direito constrói o macro cenário para a utilização, na seara da argumentação, do conceito de derrotabilidade; via derrotabilidade, uma norma jurídica pode, em situações excepcionais, deixar de ser aplicada ao caso concreto, ainda que todos os elementos de seu antecedente normativo tenham se configurado, ante o reconhecimento da existência de uma cláusula de exceção implícita;

d) A derrotabilidade se fundamenta na natureza contingente das regras e nos seus caráteres subinclusivo e sobreinclusivo; no entanto, a eficácia de trincheira das regras faz com que a derrotabilidade apenas se legitime em casos excepcionais, tendo sua utilização controlada, dentro do jogo argumentativo, pela necessidade de respeito ao princípio do qual a norma decorre, pelo respeito à justificativa da norma e pelo acatamento do mínimo sentido de linguagem que não está à disposição do intérprete;

e) Toda norma jurídica, seja regra ou princípio, é, por natureza uma moldura argumentativa, no âmbito da qual "tudo deve ser considerado" (all things considered), cuja natureza não se encontra estipulada ex ante no âmbito do texto, mas é encontrada exatamente na fase de ponderação, a partir do contexto e do caso no qual se dará a aplicação.

f) A consciência de que o Direito é um fenômeno complexo exige que a derrotabilidade seja analisada nas perspectivas estática e dinâmica, nas vertentes de derrotabilidade inferencial, baseada no processo e baseada na teoria;

g) A ideia central no âmbito da derrotabilidade inferencial é a de que a argumentação jurídica deve ser concebida como uma cadeia de garantias, no bojo da qual antecedentes justificam consequentes. A formalização lógica do fenômeno da argumentação tem por propósito afastar o decisionismo e o psicologismo, possibilitando o questionamento e eventual refutação das conclusões obtidas, mediante a análise da contraposição entre as inferências que as confirmam e as que a rechaçam.

h) No âmbito do processo, a derrotabilidade pode ser utilizada para modular o mecanismo de atribuição do ônus da prova e de sua apreciação, o que impacta diretamente a definição da verdade refletida na decisão final. Sob a ótica do juiz, ela lhe impõe o dever de 
exteriorizar, no bojo da decisão, justificação completa e coerente acerca dos fatos, de modo a viabilizar que as partes possam refutar as conclusões da decisão final de forma racional e lógica, através da constatação de circunstâncias de rebutting e overcutting que, embora por ele não percebidas, possam enfraquecer ou até mesmo inviabilizar a conclusão adotada.

Estudar o fenômeno da derrotabilidade é fundamental ao Direito porque, ao ser o instrumento que melhor retrata sua natureza dinâmica, o seu uso possibilita o desenvolvimento de uma prática argumentativa que admite a complexidade discursiva em todas as suas vertentes e interações, mas sem precisar abrir mão da racionalidade e da lógica. E embora muitas vezes a ideia de derrotabilidade soe como algo intuitivo, Schauer (2012) lembra que há sistemas legais que tratam suas normas como não derrotáveis, assim como há, nos sistemas legais que admitem a ideia de derrotabilidade, juízes que continuavam a tratar a linguagem literal como conclusiva. Sendo a derrotabilidade mais uma propriedade de determinados sistemas legais que propriamente do Direito em si, a necessidade de sua propagação se mostra absolutamente necessária.

\section{REFERÊNCIAS}

BELTRÁN, Jordi; RATTI, Giovanni. Defeasibility and Legality: A survey. In: The Logic of legal requirements. Essays on Defeasibility. Oxford University Press: 2012.

BUSTAMANTE, Thomas. Princípios, regras e conflitos normativos: uma nota sobre a superabilidade das regras jurídicas e as decisões contra legem. Direito, Estado e Sociedade. Vol no 37, jul/dez 2010, p. 152-180.

CHALMERS, A. F. O que é ciência afinal? Tradução de Raul Filker. Brasília: Editora Brasiliense, 1993.

CRUZ, Álvaro Ricardo de Souza. O discurso científico na modernidade: o conceito de paradigma é aplicável ao direito. Rio de Janeiro Lumen Juris, 2009, p. 122-162.

DAMÁSIO, António R. E o cérebro criou o homem. Tradução de Laura Teixeira Motta. São Paulo: Companhia das Letras, 2011

DAMÁSIO, Antônio R. O erro de Descartes: emoção, razão e o cérebro humano. Tradução: Dora Vicente e Georigina Segurado. São Paulo: Companhia das Letras, 1996.

FOLLONI, André. Complexidade, direito e normas jurídicas como emergências. Revista Direito \& Práxis. Vol 08, n. 02, 2017, p. 905-941.

FONTELES, Samuel Sales. O dilema do ministério público diante da derrotabilidade das regras (defeasibility). Revista do Ministério Público do RS, Porto Alegre, n. 79, jan. 2016 abr. 2016, p. 55-84 
GOULART, Eduardo Dayrell de Andrade. Observações Introdutórias sobre os paradoxos e o fenômeno da vagueza na linguagem natural. FUNDAMENTO V. 1, N. 1 - SET.-DEZ. 2010, p. 202-216

GUERRA, Marcelo Guerra. Premissas para a construção de um léxico constitucional e epistemologicamente adequado em matéria probatória. Trabalho publicado nos Anais do XIX Encontro Nacional do CONPEDI realizado em Fortaleza - CE nos dias 09, 10, 11 e 12 de Junho de 2010

HESSEN, Johannes. Teoria do conhecimento. Tradução de João Vergílio Gallerani Cuter. São Paulo: Martins Fontes, 2003.

KANT, Immanuel. Crítica da razão pura. Tradução de Manuela Pinto dos Santos e Alexandre Fradique Morujão. 5.ed. Lisboa: Fundação Calouste Gulbenkian, 2001, Introdução, itens I, II e III.

KELSEN, Hans. Teoria Pura do Direito. Tradução de João Baptista Machado. São Paulo Martins Fontes, 2003.

MACHADO SEGUNDO, Hugo de Brito. Por que dogmática jurídica? Rio de Janeiro: Forense, 2008.

MAIA, Gretha Leite. O direito como argumentação no modelo Ryle-Toulmin: uma tentativa de aproximação. In: Filosofia do direito I [Recurso eletrônico on-line] organização

CONPEDI/UFSC; coordenadores: José Alcebíades de Oliveira Junior, Robson Tramontina, André Leonardo Copetti Santos. - Florianópolis: CONPEDI, 2014.

MITCHELL, Melanie. Complexity, a guided tour. Oxford Oxford University Press, 2009.

NETO, Celso Correa. Formação do Direito Tributário como disciplina jurídica: Recortes e Exclusões. Revista Nomos. Vol 36, n.1, 2016, p.117-144.

PERELMAN, Chaim. The new Rhetoric: A treatise on Argumentation. Notre Dame, [Ind.] University of Notre Dame Press (1969)

POPPER, Karl. A vida é aprendizagem. Epistemologia evolutiva e sociedade aberta. Tradução de Paula Taipas. Lisboa Edições 70, 2001.

PRAKKEN, Henry. Logical Tools for modelling legal argument. A study of defeasible reasoning in çaw. Springer-science +Business Media, BV: 1997.

RESCHER, Nicholas. Epistemology. An introduction to the theory of knowledge. Albany State University of New York Press, 2003.

RESCHER, Nicholas. Presumption and the practices of tentative cognition. Cambridge University Press. 2006. 
SARTOR, Giovanni. Defeasibility in Legal Reasoning. In: The Logic of legal requirements. Essays on Defeasibility. Oxford University Press: 2012.

SARTOR, Giovanni. Syllogism and Defeasibility: A comment on Neil MacCormick's Rhetoric and the rule of Law. European University Institute. EU Working Paper Law n'2006/23.

SARTOR, Giovanni; PRAKKEN, Henry. Presumptions and burden of proof. European University Institute. EU Working Paper Law nº 2006/36.

SARTOR, Giovanni; PRAKKEN, Henry. The three faces of Defeasiability in the Law. Ratio Juris. Vol 17 n $^{\circ} 01$ March 2004

SCHAUER, Frederic. Is defeasibility an Essential Property of law? In: The Logic of legal requirements. Essays on Defeasibility. Oxford University Press: 2012.

SCHAUER, Frederic. Playing by the rules: A philosophical examination of rule-based decision-making in law and in life. Oxford: Clarendon Press, 1991

STRUCHNER, Noel. Formalismo, dogmática jurídica e Estado de Direito: um debate sobre o direito contemporâneo a partir da obra de Tércio Sampaio Ferraz Jr. São Paulo: Cadernos Direito GV, V. 7, n. 3, 2010.

TARUFFO, Michele. La prueba de los hechos. 3.ed. Traducción de Jordi Ferrer Beltrán. Madrid: Trotta, 2009.

TARUFFO, Michele. Uma simples verdade. São Paulo: Marcial Pons, 2016.

VAN DEEMTER, Kess. Not Exactly. In praise of vagueness. Oxford University press: New York, 2010.

VASCONCELOS, Fernando Andreoni. O conceito de derrotabilidade jurídica. Dissertação de Mestrado, Universidade Federal do Paraná: 2009, 132f.

WALTON, Douglas. Metadialogues for resolving burden of proof Disputes (February 12, 2011). Available at

SSRN: https://ssrn.com/abstract=1760402 or http://dx.doi.org/10.2139/ssrn.1760402

Trabalho recebido em 22 de fevereiro de 2019

Aceito em 20 de março de 2021 